\title{
Application of the Suitability Validation Results During Selection ${ }^{1}$
}

\section{BALLA József ${ }^{2}$ - SZATMÁRI Adrienn ${ }^{3}$ - KUI László ${ }^{4}$}

\begin{abstract}
Regarding law enforcement agencies, the selection of the appropriate staff members and the people who are qualified for professional service has received a lot of attention in the past decade, both at departmental and executive level. Along with this, aptitude tests, selection procedures, and subsequent fitting tests provide many data for the effective organisational operation and its prediction. This study looks at relevant processes within law enforcement organisations, focusing on the border police officers' suitability criteria.
\end{abstract}

Keywords: police, selection, suitability, aptitude test, competence

In the past two decades, with regards to the Hungarian law enforcement agencies, in various organisational researches particular attention was paid to the selection of sworn officers and their suitability. Fitting tests can actually be interpreted as controls of the aptitude tests; they ought to map out the validity and reliability of selection procedures. The definition of competence goes hand in hand with the selection criteria; home affairs authorities are at the fore of the elaboration of several competence systems.

Concerning the Police, two fitting tests (suitability validation) stand out: one of them is the fitting test of non-commissioned border guards and police officers conducted in 2002 in the police training schools, the other one related to this is the Twinning project between 2005 and 2007. In the framework of the German-Hungarian Twinning project, Virág et al. ${ }^{5}$ aimed at the establishment of a competence-based, integrated human resources management system supported by the Ministry of the Interior.

The project wanted to provide assistance with the support of organisational changes through meeting the requirements of a motivated, customer-driven and serviceminded management in the system of a more modern, more efficient and faster

The work was created in commission of the National University of Public Service under the priority project PACSDOP2.1.2-CCHOP-15-2016-00001 entitled "Public Service Development Establishing Good Governance" in the Ludovika Research Group Program.

2 BALLA József, PhD, Police Colonel, National University of Public Service, Faculty of Law Enforcement. https://orcid.org/0000-0002-6113-5350, balla.jozsef@uni-nke.hu

3 SZATMÁRI Adrienn, PhD student, National University of Public Service, Faculty of Law Enforcement, Doctoral School of Law Enforcement.

https://orcid.org/0000-0001-8329-2026, szatmari.adrienn@uni-nke.hu

4 KUI László, Police Lieutenant Colonel, Assistant Lecturer, National University of Public Service, Faculty of Law Enforcement, Department of Border Policing. https://orcid.org/0000-0001-6411-4179, kui.laszlo@uni-nke.hu

$5 \quad$ Hegyi (2007) 
public administration. The followings could be listed among the objectives of the project: competence mapping with setting competence and development standards, competence-based selection, overview of suitability, elaboration of performance evaluation, moreover, to discover training opportunities appropriate for the organisation's special needs, and draft the related recommendations.

The definition of suitability is intended to cover the relation between the person and the profession, furthermore, their interaction in expected, good or outstanding qualities. It is obvious that the effective attitude at the workplace, i.e. suitability, requires the knowledge of job requirements (what?), appropriate reactions to the job requirements established by the organisational culture (how?), furthermore, relevant activities determined by the personality traits (why?). ${ }^{6}$

Suitability ${ }^{7}$ indicated such a process during which employees work efficiently for a longer period of time, meeting the average requirements, avoiding accidents and without health damages. During this period, it is not sufficient to meet the expectations of a certain position, the proper quality of the organisational socialisation process is also part of it. Regarding suitability, objective and subjective factors could be mentioned. ${ }^{8}$

Table 1: Suitability factors. Source: Table drawn by the authors.

\begin{tabular}{|l|l|}
\hline \multicolumn{1}{|c|}{ Objective indicators } & \multicolumn{1}{c|}{ Subjective indicators } \\
\hline quantity and quality of performance & $\begin{array}{l}\text { relationship between the employee and his/her colleagues, } \\
\text { subordinates, superiors, communication style }\end{array}$ \\
\hline efficiency & satisfaction-dissatisfaction \\
\hline proportion of absenteeism and presence & flexible attitude, creativity, inventiveness \\
\hline commitment & autonomy at work, being able to work without supervision \\
\hline career growth & ability to lead others \\
\hline training performance & results in the achievement of performance goals \\
\hline expertise & knowledge of job requirements \\
\hline
\end{tabular}


Competence is a basic ability, personal trait, motivational aspect which is necessary to perform an excellent work; it is measurable and can be developed. In case of each organisation, kind of work and position there are general and special competences, too which constitute solely a small part of the full competence models. One personal trait can be a competence in case it is relevant concerning the performance, and other personal traits cannot be used for individual performance evaluation. In case of sworn officers at law enforcement agencies, the general characteristics of the competences are: ${ }^{9}$

- continuous 'validity';

- emphasis on the actual behavioural features which are necessary to perform duty;

- expansion capability, adaptability and the back-to-back feature of the competence systems;

- coherent framework and language, ideation;

- predictability, transparency;

- results can be reconsidered;

- differentiation (general and specific);

- integration of researches, experiences;

- efficient participation in daily and practical work.

The competence systems concerned, which set a clear requirement system for both individuals and the organisation, accurately define the features of those skills, knowledge and personal traits which are necessary to do an efficient and excellent work. These appear in the selection, training, development and performance evaluation, as well.

Aptitude tests mean compliance between the requirements and opportunities of a certain position, and the applicant's competences, furthermore, they also aim at the detection of individual differences. Aptitude tests promote employees' placement and operation in such positions which correspond to their interests and abilities the most.

During selection, suitability tests mean the prediction of an employee's behaviour, performance at the workplace and work quality through conducting targeted tests. This way, the number of those persons can be increased who perfectly fit the job at their new workplace. Klein ${ }^{10}$ emphasises that work-related knowledge is a significant criterion during selection which contains internal (aim of the work, employee's tasks, work conditions) and external (job description, desired behavioural repertoire related to work, competence model, educational needs etc.) aspects. With regards to the selection models, ${ }^{11}$ Thorndike's traditional theory shall be highlighted who considered work and people separate units, moreover, he applied the principle of the 'right man in the right place'. If we look at it, it is the description of the suitability technique. The model studied the criteria of efficient work with the help of job analyses, moreover, the probability of suitability too, and later, it was expanded by the definitions of job satisfaction theories.

\footnotetext{
Szelestey (2007)

Klein (2004)

11 Hegedűs (2014)
} 


\section{Suitability Validation at the Police}

The fitting test of non-commissioned border guard and police officers conducted in $2002^{12}$ discovered that the suitability validation of the studied staff category required at least half a year, at most a period longer than 3 years. $60-70 \%$ of the staff can be considered suitable; its success depends on the personal traits and competences, while failure usually derives from the organisational structure, management system, operational difficulties and prevailing approach. It was important that leaders indicated a relative balance between the factors promoting and hampering suitability, while non-commissioned officers highlighted mainly the presence of complicating factors.

In addition to this, the investigation also revealed several components concerning the optimisation of the training system. It shall be noted that, from the perspective of successful suitability, workplace plays a greater role than the acquisition of general knowledge preparing for the performance of professional tasks, or the law enforcement training. Performance is one indicator of suitability which, however, confirms to have a close correlation with the training quality.

It has appeared among the recommendations that it would be justified to replace the selection and educational institution application systems with a competence-based solution which is better adapted to the job contents.

In the framework of the Twinning project, also the suitability criteria regarding home affairs organisations were set out in the research conducted ten years ago. According to the conclusions and organisational phenomena at that time, those sworn officer could be considered suitable who met the following requirements: was a member of the organisation for at least four years, precisely knew the job requirements and complied with the competence levels related to his/her job. His/her performance was at least on medium level that he/she could achieve without physical and mental damages. He/she was able to work autonomously complying with the provisions. His/ her professional preparedness was relevant from the perspective of his/her job, he/ she was able to apply his/her theoretical knowledge in practice as well, continuously followed the legal-organisational changes. He/she was professionally recognised, was mentioned as a leader model, enjoyed recognition, he/she was awarded. Joy in work and satisfaction were characteristic for him/her, had sense of achievement many times, enjoyed himself/herself at the workplace, eventually, he/she was motivated. He/she was open to development, self-learning. He/she was loyal to his/her organisation, identified with the organisational norms and objectives. He/she was integrated into the working environment where cooperation skill was characteristic for him/her.

12 Virág et al. (2004) 


\section{The Selection System of Law Enforcement Agencies with Regards to the Applications to Law Enforcement Educational Institutions}

The selection system of law enforcement agencies represents a quite complex, constantly changing and developing structure. Generally speaking, most sworn officers have been preparing for years - already during the secondary-school years - for starting their law enforcement career. The first manifestation of career motivation is usually the participation in education at a specialised secondary school which used to be secondary or vocational school education with home affairs specialisation (today it is called Law Enforcement and Civil Service Specialisation). This could be considered the zero level of selection; a watershed; the period of preparation for sworn officer duties when it is possible to acquire special knowledge, to lay the right career foundation and to target the preparation. Those pupils who are interested in a law enforcement career - coming from specialised or non-specialised secondary schools - can apply to the chosen law enforcement specialised high schools after the Baccalaureate.

In recent years, the secondary school education with policing specialisation has undergone several reorganisations as regards the duration of training, particular selection aspects, and also the name. In the framework of a training providing qualification listed in the National Qualification Register, police officers are educated in four law enforcement specialised schools (Adyliget Law Enforcement Vocational School, Körmend Law Enforcement Vocational School, Miskolc Law Enforcement Vocational School, Szeged Law Enforcement Vocational School). The duration of these trainings is two or one and a half years depending on whether the applicant has relevant professional bases and secondary school knowledge. Beyond this, part-qualifications in the framework of other, non-formal education can also be mentioned as an entry opportunity for the future or already employed county staff members (e.g. guard-patrol partner training, the current border hunter training) in the training spectrum offered by specialised high schools. ${ }^{13}$

At the same time, it is also possible to enter the regular staff through the higher educational segment which opportunity is provided by the Faculty of Law Enforcement at the National University of Public Service through offering several specialisations. The Faculty of Law Enforcement at the National University of Public Service provides such trainings which are necessary in order to fill those positions which require higher education qualifications at the Police, the National Directorate General for Disaster Management, the Hungarian Prison Service, Immigration and Asylum Office, the National Tax and Customs Administration, moreover, in the various fields of expertise of private security services. Currently, according to university prospectuses and regulations, students can be enrolled in 3-year-long, and from the 2017/2018 school year, in 4-year-long BA programmes on a full time basis or as correspondence BA programmes, furthermore, in 2-year-long distance learning MA programmes. In addition, from the

13 Molnár-Balla (2017) 
2016/2017 school year, those students, who are enrolled in law enforcement courses on a full time basis, have 'officer candidate' status.

Border police officers, who are the focal points of this research, are trained in the BA programme in Law Enforcement Administration, Border Policing specialisation to perform their law enforcement duties. ${ }^{14}$ The expectation is to have such a qualified staff as an output who have special border policing knowledge, and are able to understand the tasks related to border control, border surveillance, criminal intelligence, border policing management, alien policing, asylum and public order. In case of the programme, the duration of which will expand to four years, the BA programme in Law Enforcement, Border Police specialisation is going to replace the former names; its content is adjusted to the new organisational-social expectations.

The output criteria are the followings: staff members shall have thorough knowledge regarding those leadership and management theories which cover the organisational structure, operation and management of the border policing service branch of the Police. Moreover, they shall have professional border policing knowledge concerning the EU and Schengen normative regulations, agencies and strategies. They shall be able to navigate in the European Union's border policing information and information processing systems, furthermore, to perform integrated border management, border policing management and other professional tasks, and to handle conflicts resulting from the migration situation. Overall, the basic concept of law enforcement training is to provide various law enforcement agencies with such officers and non-commissioned officers as outputs who have up-to-date professional knowledge, moral values and personal traits in order to be suitable both in the home country and abroad. ${ }^{15}$

In case of those persons who are interested in a law enforcement career, with regards to both law enforcement high schools and university education, it is a general requirement to meet the criterion of entering service as a sworn officer, and to meet the selection and admission requirements. So, those persons can be members of a law enforcement agency who are capable of action, have their domicile in Hungary, have Hungarian nationality, and attained the age of eighteen. In addition, they shall have particular qualifications; health, psychological and physical qualifications based on which they are fit for duty; an unimpeachable background check, furthermore, - if their service grade justifies it - they shall have the positive, approved result of the national security check. Generally speaking, it is about such a person who is aware of and accepts the obligations and expectations laid down by regulations concerning service and duty, moreover, the limitation of particular fundamental rights by the Police Service Act. ${ }^{16}$

Among the requirements of duty service, as a special employment, public service status, clean criminal record, unimpeachable lifestyle (as regards the person himself/

\footnotetext{
Balla (2017a); Balla (2017b)

Boda (2016)

2015. évi XLII. törvény (IV. 24.) - a rendvédelmi feladatokat ellátó szervek hivatásos állományának szolgálati jogviszonyáról - VI. 25. Availabe: http://njt.hu/cgi_bin/njt_doc.cgi?docid=175262.348597 (Downloaded: 10.05.2018.)
} 
herself and his/her close relatives), fitness, health and mental status are also subjects to check besides the employment criteria when applying to law enforcement educational institutions. In case of specialised high schools, it is a further admission requirement for the 2-year-long training to examine the applicant's level of literacy; and to have a successful human resources interview concerning both trainings with different duration. As regards the Faculty of Law Enforcement at the National University of Public Service, the age group is narrower (18-25 years) the members of which can apply for the full-time law enforcement programmes in the case of most specialisations and they shall have an intermediate-level (B2) complex language exam recognised by the state or an equivalent European Baccalaureate.

The admission point score system and the structure of evaluation regarding the physical, mental and health aptitude constitute further differences concerning the two training programme types.

\section{Selection and Suitability in the Course of Regular Duty Service}

With regards to duty service, physical assessment tests shall regularly be conducted and assessed prior to establishing and also in the course of the service status which is regulated by Act 57/2009 (X. 30.) jointly issued by the Ministry of Justice and Law Enforcement, the Ministry for Local Government and Regional Development and the Minister without Portfolio (on the Health, Psychological and Physical Fitness of the Regular Staff of Certain Law Enforcement Bodies, the Occupational Fitness of Civil Servants and Public Servants and Determining Capacity to Serve and Earn). Aptitude tests are conducted by the primary care physician of the specific agency, furthermore, its psychologist and a colleague who has physical education or sports expert qualification according to uniform professional principles, methods and criteria complying with the professional protocols. The types of aptitude assessment tests in the course of and prior to the service status are the followings according to the relevant act:

- prior to promotion to regular service, re-employment or entering the Police's special employment staff category (senior staff);

- when applying to law enforcement educational institutions;

- periodically in the course of the service status;

- prior to someone's position in the regular staff will be fix;

- prior to displacement from other law enforcement agencies or the Hungarian Army;

- prior to change in position;

- prior to deployment to special service;

- prior to and in the course of civil servant or public servant service;

- as a matter of urgency;

- prior to promotion to commander in duty;

- prior to and following deployment to foreign service. 


\section{Selection System Concerning the Ministry of the Interior's Management}

Selection procedures provide a complex assistance not only in case of employed staff but also in case of management. They promote duty to be as efficient as possible and also the suitability of those staff members who actually or allegedly have management skills and abilities.

From 1 March 2013, the Decree of the Minister of the Interior No. 2/2013 (I. 30.) (on the further training and management training system of the members of the official personnel of agencies reporting to the Minister of the Interior and on the replacement and management databank of law enforcement) - which has been amended several times since then - stipulates that such a person can be promoted to the position of 'Head of Division' or to a higher-level management position as regards law enforcement agencies who meets the selection procedure requirements set out by the Decree, and successfully meets the management training criteria laid down for that particular management level.

In addition to this, the Decree also includes the criteria system of the training to become a law enforcement leader or master leader, the objective of the talent support programme and its admission requirements. ${ }^{17}$ As part of the central human resources registry, law enforcement agencies have databanks concerning the junior staff and leadership which assist the concerned regular staff member's planned promotion - based on merits and performance - and also facilitates to fill the fix law enforcement management positions with the appropriate persons. ${ }^{18}$

In addition, the Decree of the Minister of the Interior No. 31/2015 (VI. 16.) (on the human resources management concerning the members of the official personnel of law enforcement agencies reporting to the Minister of the Interior) makes it compulsory for the given agency to nominate at least three leader candidates (who meet the qualification requirements) when promoting someone to the vacant management position. The Ministry of the Interior's new management selection procedure is conducted at the Department of Management Training, Development Training and Science Administration of the Ministry of the Interior - the name of which has been amended several times - where leader candidates will be listed in an order in a preliminary opinion based on to what extent the certain competency profiles match with the leadership competency profile contexts required by that management position. ${ }^{19}$

The new integrated leadership selection system is based on complex and organisation-specific researches during which a methodological procedure has been elaborated and a complex IT system has also been established focusing on the Ministry of the Interior's management competences. The foundations of the management selection system were laid and its elaboration took place between 2012 and 2014 in the framework

\footnotetext{
17 Rigó-Simon (2016)

18 2015. évi XLII. törvény a rendvédelmi feladatokat ellátó szervek hivatásos állományának szolgálati jogviszonyáról, 277. §. Available: http://njt.hu/cgi_bin/njt_doc.cgi?docid=175262.348597 (Downloaded: 10.05.2018.)

19 Münnich et al. (2016)
} 
of the ÁROP-2.2.17-2012-2013-0001 “New public administration carrier plan" project with the assistance of the Scientific Council for Domestic Affairs and the Ministry of the Interior, Directorate for Education, Training and Science.

The system includes 13 home affairs leadership competences on two levels: it assesses the quality of leadership skills and abilities on middle-management (Head of Division and Deputy Head of Department) and high-management level (Head of Department and higher-level positions). With regards to the two leadership segments, both the overlapping and distinct expectations of leaders, moreover, also the individual, social and primarily leadership competences can be seen (Table 1).

A leader's suitability is validated if, on the middle-management level, principally the everyday operation of the own, smaller organisational unit while, on the high-management level, the management of a global organisation, innovative coordination from a managerial point of view and efficient establishment of external relations can be observed. ${ }^{20}$

The leadership selection procedure consists of three parts where the particular parts assess the 13 leadership competences sometimes with a shift in emphasis, sometimes in a weighted manner. The candidates' results are based on the results of the Comprehensive Leadership Selection Test, the individual, collaborative and group exercises in the framework of an assessment centre (AC), furthermore, the semi-structured competencebased leadership interview. The final result is presented during a one-to-one feedback session where it is possible to clear the questions arising. Such a competency profile is built in case of the candidates which is based on stanine and can be compared to the leadership competency profile defined and required by the leadership of the agency concerned.

Following the successful completion of the leadership selection procedure, the candidate will be registered in the databank of junior staff or leadership, moreover, he/she will be enrolled in a course to become a law enforcement leader or master leader which he/she shall accomplish.

\section{Basic Law Enforcement Competences}

Modelled on the home affairs leadership competences, also the basic law enforcement competences (Table 3) were elaborated with the assistance of the Scientific Council of the Hungarian National Police in the framework of the PACSDOP-2.1.5-CCHOP-16 "Strategic support for the replenishment with staff concerning the competitive public service" project based on the uniform basic competences in public administration. ${ }^{21}$

\footnotetext{
20 Malét-Szabó (2015)

21 Malét-Szabó et al. (2018)
} 
Table 2: Uniform basic competences in public administration. Source: Table drawn by the authors.

\begin{tabular}{|c|c|c|}
\hline & Basic competence & Definition \\
\hline 1 & Decisiveness & $\begin{array}{l}\text { Recognises situations requiring decisions and based on the available information, makes } \\
\text { such an optimal decision which could be expected in that case. }\end{array}$ \\
\hline 2 & Cooperation & In order to perform his/her tasks, coordinates his/her actions and behaviour with others. \\
\hline 3 & Emotional intelligence & $\begin{array}{l}\text { Recognises and understands his/her and other persons' emotional state, moreover, cor- } \\
\text { relations between behaviours resulting from this state. Deals with them according to the } \\
\text { particular situation. }\end{array}$ \\
\hline 4 & Ownership & $\begin{array}{l}\text { When performing the task, recognises and takes into account the consequences of his/her } \\
\text { decisions, actions and reports on them. }\end{array}$ \\
\hline 5 & Responsibility & $\begin{array}{l}\text { Being aware of his/her own abilities and opportunities, he/she is able to take firm actions } \\
\text { in order to obtain the organisational objectives. }\end{array}$ \\
\hline 6 & Efficient work & $\begin{array}{l}\text { Professionally and carefully performs his/her tasks. Able to optimally exploit the available } \\
\text { resources. }\end{array}$ \\
\hline 7 & Communication skills & $\begin{array}{l}\text { Able to clearly express himself/herself verbally and in writing according to the situation. } \\
\text { Able to understand others' communication in a proper way. }\end{array}$ \\
\hline 8 & Conflict management & $\begin{array}{l}\text { Able to apply such methods or styles in controversial situations with the help of which } \\
\text { conflicts can be eased. }\end{array}$ \\
\hline 9 & Autonomy & $\begin{array}{l}\text { Building on his/her knowledge and experiences, he/she is able to perform the assigned } \\
\text { tasks without constant supervision and guidance. }\end{array}$ \\
\hline 10 & Problem solving skills & $\begin{array}{l}\text { Able to identify the occurring problems and draft solution opportunities. Able to choose } \\
\text { such an alternative from the possible ones which results in the optimal solution. }\end{array}$ \\
\hline 11 & Mental loadability & Able to keep and maintain his/her effectiveness in difficult, stressful situations. \\
\hline 12 & $\begin{array}{l}\text { Compliance, } \\
\text { discipline }\end{array}$ & $\begin{array}{l}\text { Able to learn the rules and norms imposed on him/her, comply with them and apply them } \\
\text { in a proper manner. }\end{array}$ \\
\hline
\end{tabular}

It is visible that there is overlapping between the basic and leadership competences in many cases. While the indicators of individual suitability, adaptability to the organisation and duty service are mostly present among the basic competences, in addition to these, leadership also contains social-organisational functions.

In case of basic competences concerning public service, which take on even greater significance during the regular staff membership, the specific competency system of the particular law enforcement fields (e.g. border policing field of expertise) is currently under establishment. The integrated competence-based selection and training system (KOMP system) incorporates the characteristics of the fields of expertise in a targeted 
manner through the elaboration of such analytical methodologies which are able to assess the focal points of the different fields of expertise, moreover, through providing a complex IT framework. The functionality of the KOMP system will be complete through these actions which clearly enables the conscious HR support of an individual's career path in a planned way. ${ }^{22}$

\section{Performance Evaluation}

The review of the selection and its efficiency takes place at the time of the first competence-based performance evaluation or aptitude test when it becomes visible how the individual's previous results have improved, and it may be seen in which field and how much he/she shall develop in order to meet the higher requirements set by the job concerned.

The performance evaluation of the Police's regular staff is based on the Government Decree No. 10/2013. (I. 21.) on the individual benchmarking in the public service and Act XLII of 2015 on the Service Status of Professional Members of Law Enforcement Agencies. The individual performance evaluation contains compulsory and recommended components. When determining the level of individual performance evaluation, the organisational performance evaluation of the place of employment of that year - conducted according to the timetable and aspects set out by the Minister - shall be taken into account. The degree of performance in relation to the level of performance evaluation can be excellent, good, satisfactory, under average or unacceptable. ${ }^{23}$

The competence-based evaluation of the workplace behaviour is conducted in the following categories according to the Government decree:

- evaluation factors of professionalism;

- evaluation factors of orderliness;

- evaluation factors of loadability;

- evaluation factors of working time;

- evaluation factors of personal and social competences;

- quality aspects of leadership (criteria for the evaluation of employees in leadership positions).

In the framework of the ÁROP 2.2.5 "Human resource management in the central public administration" project, a system for individual performance evaluation concerning public service was elaborated. In this system, the evaluation is conducted electronically, based on common methodology, and with the help of an integrated public service IT system. The following competences are listed in the Police's current performance evaluation system: ${ }^{24}$

- decisiveness;

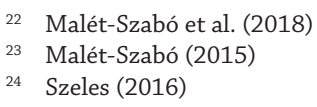


- managing/leading groups;

- ability to apply other types of knowledge (e.g. foreign language, IT knowledge);

- ethical behaviour/reliability;

- responsibility;

- determination, confidence;

- integrity;

- communication;

- conflict management;

- understanding others (empathy);

- motivating others;

- development of colleagues;

- autonomy;

- systems thinking;

- flexibility;

- strategic (analytical, conceptual) thinking;

- rule consciousness and discipline;

- level of applying professional knowledge;

- loyalty towards the organisation;

- organisational skills;

- performance evaluation skills;

- planning skills;

- customer orientation (partner oriented approach);

- managing change;

- openness to changes, sense of initiative;

- ability to jointly apply management techniques (plan, organise, lead, manage, decide, set requirements, delegate, supervise).

\section{Suitability Validation Tests Concerning the Border Policing Regular Staff}

Based on the experiences of the prior Police suitability validation tests, the border policing regular staff's testing was also started in the first half of 2018 in the framework of the current project. In order to make the future survey-based research ready, qualitative, structured interviews have been recorded with members of the leadership at the border police authorities. The outline of the interview followed the prior researches and was primarily based on leadership-expert experiences; and shows the mapping of the interviewees' personal opinions, evaluations and expectations of employees. 10 border policing leaders on middle- and higher-management level (Head of Divisions, Head of Department) appeared in the expert interviews who have country-wide experiences due to the various work locations.

Our questions have studied the following main topics:

- definition concerning suitability validation; 
- suitability criteria (promoting and hampering factors, time, efficiency);

- characteristics of the border policing staff;

- quality and usefulness of the border policing training;

- components of fluctuation.

Based on the answers given to the questions and the results of content analysis, the followings can be established:

1. In your opinion, what makes a border police officer suitable?

In the border policing leaders' opinions, a suitable border police officer is prepared, demonstrates professionally consistent performance, shows autonomy at work and is able to develop, applies the proper professional knowledge on the proper level in the border policing field of expertise. Such a person is committed, dedicated, has an appropriate attitude, can deal with heavy workload, enthusiastic and motivated. This person is a team player who envisages his/her future in the border policing field of expertise.

2. In your point of view, which are the suitability criteria

a) from an organisational perspective?

The organisational criteria of suitability are loyalty, dedication, serving and understanding the organisational objectives, reliability and the ability to follow orders.

b) from the perspective of the organisational unit?

The criteria of suitability from the perspective of the organisational unit are professionalism, understanding of the professional job, autonomy, decisiveness, resilience, commitment, development needs, reliability, accuracy and flexibility.

c) from an individual perspective?

The criteria of suitability from an individual perspective are the development needs, autonomy, appropriate individual competences, best practice and knowledge, reliability, dedication and loyalty.

3. Which factors promote suitability

a) from an individual perspective?

Factors promoting suitability from an individual perspective are motivation, community thinking, care, helpfulness, positive working environment, upbringing, family environment, schooling, individual visions meeting organisational visions, work-related feedback, professionalism, curiosity.

b) from an environmental perspective?

Environmental factors promoting suitability are assistance, teamwork, positive working environment and atmosphere, camaraderie, supporting environment, good working conditions (predictable working time), development opportunities, family background, family/work balance, respect of the citizens.

4. Which factors hamper suitability

a) from an individual perspective?

Individual factors hampering suitability are lack of loyalty, bureaucracy, hierarchy, indifference, demotivation, lack of development needs, lack of (positive) feedback 
and support, constant negative feedbacks, lack of schooling and discipline, moreover, serving far from residence and family.

b) from an environmental perspective?

As regards environmental factors, identification difficulties, unpredictability, unsatisfactory labour conditions, lack of career opportunities, inefficient training system, conflict at the workplace, insecure family background, distance and excessive antipathy of the citizens hamper suitability.

5. Which events indicate suitability?

Event indicating suitability are career growth, autonomous, flawless work or work with few errors, efficient and responsible work, decisiveness, positive approach, positive mood, networking, staying at the organisation, leadership merit and award.

6. Which events indicate that a border police officer is not suitable?

Events indicating lack of suitability are the drop-out of this career path, change in the area of expertise if there are no work results, lack of autonomy, recurring errors, demotivation, indifference, negative approach, negative leadership opinions and disciplinary proceedings.

7. How much time is required to consider a border police officer suitable?

With regards to suitability time, the consulted persons determined a wide time interval (between 1 and 10 years); border police officers are considered suitable within slightly more than 4 years in average (average $=4.33$ ) but individual differences were emphasised too.

8. What percentage of the border police regular staff, who you know, do you consider suitable?

Currently, the consulted leaders consider $61 \%$ (average $=61.25 \%$ ) of the regular staff suitable but they formulated different, extreme opinions when evaluating this (between 10-90\%).

9. What kind of strengths does the border police regular staff have?

According to the consulted persons, the regular staff's strengths derive from the organisational culture, cohesion, expertise, preparedness, logical way of thinking, good and prompt reactions to unexpected situations, problem solving, resilience, empathy (towards employees and citizens), appropriate local knowledge of the border territory, furthermore, ability to take measures and take into account the logistics.

10. What kind of weaknesses does the border police regular staff have?

With regards to weaknesses, the lack of motivation, practice, autonomy, sense of initiative and creativity must be highlighted besides the formulaic and unprofessional approach, lack of language skills and IT knowledge. In many cases, deficiencies derive from the fact that they are still not properly integrated into the Police's organisation.

11. Which are the areas to be developed concerning the border police regular staff? Regarding fields to be developed, the consulted persons outlined the autonomous decision-making, efficient cooperation and problem solving, treating the people in a humane manner, trainings for the leadership-commander job, language skills, international and IT experiences, moreover, the integration of the complex law enforcement perspective. 
12. In your opinion, in which fields do/did graduated students receive proper trainings?

The consulted persons mentioned mainly the general and border policing theoretical training as a proper training field. In addition to these, they put a great emphasis on the areas of expertise of law, foreign language, IT, leadership-management and public administration.

13. In which fields do/did they not receive proper training?

They felt rather unsatisfied with the practical knowledge, furthermore, IT knowledge, commander-leadership operation and measure tactics knowledge shall be improved.

14. Is there a difference between those border policing students' suitability who graduated at different educational institutions (e.g. NUPS, former: Law Enforcement College, Lajos Kossuth Military College)?

The majority of the consulted leaders considered the Lajos Kossuth Military College students' suitability better. A more efficient commander operation was mentioned during the evaluations but we experienced that they highlighted the disappearance of differences too. According to some leaders, law enforcement students benefit from the current system, they master the professional knowledge during their organisational socialisation process. Although they were trained for another field, they have the same chances when it comes to suitability.

15. To what extent does the training meet the job requirements of border police officers?

Regarding the relation between the training and requirements, leaders underlined a partial (half-half) consistency. They considered the legal and professional knowledge to be proper but the leadership-commander knowledge should be made clearer. According to their opinions, differences derive from the fact that although proper training is provided, higher and higher requirements are set out.

16. How could the training be better coordinated with the tasks occurring during service and duties?

As regards proposals, the development of the practical training aspects (situational exercises - service organisation, briefing, interview with the commander) appeared without exception. In order to support this, it is recommended to establish a more serious mentor system or, for example, to invite recognised guest officers. It appeared as a difficulty that due to the constantly changing task system, if there is a change in the training system, often it is possible to have a follow-up only.

17. What could foster border police officers to stay at the border policing service branch?

The consulted leaders said that predictability, love of job, proper career and salaries, career growth and development opportunities, leadership receptive to new proposals, more humane service organisation, reasonable requirements, place of employment close to the residence, individual motivating benefits and foreign study visits are such aspects which contribute to staff retention capabilities. To this end, it is essential to select the proper students, it is proposed to select them from the non-commissioned 
officer staff, and furthermore, the esteem and respect toward the border policing area of expertise within the Police's organisation are also indispensable.

18. What does the phenomenon of fluctuation influence in case of the service branch?

Fluctuation is influenced by lack of career growth, lack of staff retention capabilities compared to the civil sector (the consistency between salaries and expected tasks is problematic), the complexity and quantity of the work to be done, lack of tolerance towards mistakes, moreover, more progress checks and increased workload. In many cases, applicants do not consider this career to be a profession which is deepened if the incorrect premises will not be corrected and the pieces of information are inaccurate.

19. What did you do to promote suitability?

With regards to the leadership support of suitability, several commander care aspects emerged, for example, the efforts to satisfy individual needs, interviews, proposing trainings, effective mentoring and supervision (positive feedback, guidance), emphatic and patient attitude, professional assistance, cooperation, teamwork and ensuring cohesion. The leaders' self-development can greatly contribute to all these.

20. What could still be done?

Concerning this question, the various benefits (pension, recreation, studies), periodically organised forums and the opportunities of the educational reform (practical training) were mentioned. Targeted selection is a significant point which is only possible along reasonable information. Nevertheless, development ideas appeared also on individual level (e.g. closer relationship with the staff during free time activities).

21. Is there anything else we have not talked about and you consider significant? The following ideas, terms emerged as such thoughts which shall be specified: proportional task distribution on country-level, esteem, respect, fluctuation within the organisation (border police officers are at a different place).

From the summary of the interview results, it shall be highlighted that among the suitability criteria, both professional and personality-related factors appeared with emphasis on the general (e.g. loyalty, motivation, and loadability) and professional characteristics (e.g. future vision in the border policing career). The suitability time (4.33 years) show a slightly increasing trend while the staff, whose suitability can be considered validated, shows similar ratio (61\%) compared to previous researches. The regular staff's strengths are organisation-specific (e.g. cohesion, prompt reaction, and resilience); concerning weaknesses, the lack of practical knowledge and leadership skills, abilities and their improper quality can be outlined. Regarding the educational system, the consulted leaders put a great emphasis on the general and border policing knowledge, however, besides the high-level theoretical training, the restructuring of practical training was proposed so that the training and job requirements could be in balance. As regards fluctuation, the balance between private life and workplace, performing service far from the family and the typical police obstacles (e.g. working condi- 
tions, career growth-related difficulties, benefits of the public sector) were problematic. The consulted leaders represent a high-level commander care with regards to supporting suitability; they try to integrate their employees into the organisation at several platforms, to support and enhance their performance.

\section{Summary}

The increasing popularity of suitability validation tests with regards to the different selection methodologies reflects the significance of selection efficiency. Concerning the Police, several suitability tests have previously been conducted, and it is a currently ongoing process according to the relevant decrees in the framework of the distinct aptitude tests and selection procedures. In this study, the different law enforcement selection procedures have been reviewed as regards new joiners, employees and leadership focusing on the different competency measuring procedures.

Along the wide theoretical frameworks and previous research results, the suitability testing of the Police's border police regular staff was started in the framework of this project in the first half of 2018. Its first step was a qualitative research where the personal opinions, experiences and expectations of members of leadership at the border police authorities were summarised.

\section{REFERENCES}

Balla József (2017a): Felsőfokú szakirányú képzés a Határrendészeti Tanszéken 2005-ben és 2015-ben. In Varga János ed.: A határrendészeti tisztképzés negyedszázada. Budapest, Dialóg Campus Kiadó. 47-54.

Balla József (2017b): Border Guard Training in Hungary Ensuring the Security of the Schengen Area. Hadtudományi szemle, Vol. 10, No. 3. 449-462.

Boda József (2016): A Nemzeti Közszolgálati Egyetem Rendészettudományi Kar feladatai a rendészeti képzésben. Határrendészeti Tanulmányok, Vol. 13, No. 1. 4-22.

Boyatzis, Richard E. (1982): The Competent Manager: A Model for Effective Performance. New York, Wiley.

Hegedús Judit (2014): A vezető-kiválasztás elméleti háttere. In Hegedűs Judit ed.: Tanulmánykötet a belügyi vezetô-kiválasztási eljárásról. Budapest, Belügyminisztérium. 5-9.

Hegyi Hella (2007): Kompetencia alapú személyzet-kiválasztás a rendészeti szerveknél. Pécsi Határör Tudományos Közlemények, No. 7. 147-151.

Hegyi Hella (2009): A munkapszichológia és a szervezetlélektan szerepe a rendvédelemben. Pécsi Határör Tudományos Közlemények, No. 10. 265-270.

Klein Sándor (2004): Munkapszichológia. Budapest, Edge 2000 Kiadó.

Malét-Szabó Erika (2015): Az új belügyi vezető-kiválasztási rendszer elemeinek értékelése a szilárd erkölcsiség mutató mérésére javasolt SZEMmodell tükrében. In Malét-Szabó Erika ed.: Az erkölcsi értékrend és a személyiség közötti kapcsolat vizsgálati szempontjai. Budapest, Belügyminisztérium. $156-191$.

Malét-Szabó Erika - Hegyi Hella - Hegedús Judit - Szeles Erika - Ivaskevics Krisztián (2018): Rendöri alapkompetenciák az egységes közszolgálati alapkompetenciák tükrében. Available: www.bm-tt. hu/rtt/assets/letolt/rt/201801/04_Szeles_Erika_Rendori_alapkompetenciak.pdf (Downloaded: 10.05.2018.) 
Molnár Henrietta - Balla József (2017): A határrendészeti továbbképzés helyzetértékelése. Határrendészeti Tanulmányok, Vol. 14, No. 4. 4-27.

Münnich Ákos - Malét-Szabó Erika - Rigó Bernadett - Szatmári Adrienn (2016): A bevezetett új vezetö-kiválasztási eljárás során keletkezett (összesitett és rész-) eredmények összefüggéseinek feltárása az egyéni jellemzôkkel. Budapest, Belügyi Tudományos Tanács.

Rigó Éva Bernadett - Simon Mária (2016): A vezetőkiválasztás egykor és ma - megfeleléstől az eredményességig. Pécsi Határőr Tudományos Közlemények, No. 17. 253-258.

Szeles Erika (2016): Módszertani útmutató - a Rendörségnél végzett pszichikai alkalmassági vizsgálatok és az ahhoz kapcsolódó gondozási tevékenység szakmai protokollja. Budapest, ORFK Személyügyi Főigazgatóság Egészségügyi Szakirányító és Hatósági Főosztály.

Szelestey Judit (2007): Kompetencia modul. In Virág László et al.: Összefoglaló tanulmány a kompetencia alapú HR-rendszer alkalmazásához. Budapest, Európai Twinning Projekt, Duna Palota Kulturális Kht. kiadója. 31-130.

Virág László szerk. (2009): A rendvédelmi pszichológiai tevékenység szakmai protokollja. Budapest, Rendőrség Tudományos, Technológiai és Innovációs Tanács.

Virág László - Szeles Erika - Könyves Tóth Előd (2004): Kutatási jelentés - A rendészeti szakközépiskolákban 2002 júniusában végzett határőr és rendôr tiszthelyettesek beválásvizsgálata. Budapest.

\section{Legal References}

2015. évi XLII. törvény (IV. 24.) a rendvédelmi feladatokat ellátó szervek hivatásos állományának szolgálati jogviszonyáról. Available: http://njt.hu/cgi_bin/njt_doc.cgi?docid=175262.348597 (Downloaded: 10.05.2018.)

57/2009. (X. 30.) IRM-ÖM-PTNM együttes rendelet az egyes rendvédelmi szervek hivatásos állományú tagjai egészségi, pszichikai és fizikai alkalmasságáról, közalkalmazottai és köztisztviselői munkaköri egészségi alkalmasságáról, a szolgálat-, illetve keresőképtelenség megállapításáról, valamint az egészségügyi alapellátásról. Available: http://njt.hu/cgi_bin/njt_doc.cgi?docid=125025.356036 (Downloaded: 10.05.2018.)

2/2013. (I. 30.) BM rendelet a belügyminiszter irányítása alá tartozó szervek hivatásos állományú tagjainak továbbképzési és vezetőképzési rendszeréről, valamint a rendészeti utánpótlási és vezetői adatbankról. Available: http://njt.hu/cgi_bin/njt_doc.cgi?docid=158730.348992 (Downloaded: 10.05.2018.)

31/2015. (VI. 16.) BM rendelet a belügyminiszter irányítása alá tartozó rendvédelmi feladatokat ellátó szervek hivatásos állományát érintő személyügyi igazgatás rendjéről. Available: http://njt.hu/ cgi_bin/njt_doc.cgi?docid=176147.348441 (Downloaded: 10.05.2018.) 